Sains Malaysiana 49(6)(2020): 1273-1282

http://dx.doi.org/10.17576/jsm-2020-4906-05

\title{
Ameliorative Effect of Apple Pomace and Mango Peels against Hyperlipidemia and Lipid Peroxidation Induced by Hyperlipidemic Diet
}

(Kesan Amelioratif Buah Epal dan Kulit Mangga terhadap Hiperlipidemia dan Peroksidasi Lipid disebabkan oleh Diet Hiperlipidemik)

\author{
Huma Umbreen*, Muhammad Umair Arshad, RaZia NoreEn \& Kiran AftaB
}

\section{ABSTRACT}

Diet induced hyperlipidemia is a major cause for atherosclerosis, lipid peroxidation, and fatty liver diseases. Fruit processing waste rich in dietary fiber and antioxidant capacity can be an economical way to manage such risk factors. The major objective of the present study was to manage hyperlipidemia by including apple pomace and mango peels in daily diet. Dry powder obtained from apple pomace, mango peels and their mixture was added to the normal chow on replacement basis by $12 \%$. These were fed to the rats along with hyperlipidemic diet to the experimental groups $(N=30,10 /$ group $)$, while control group $(N=10)$ was fed hyperlipidemic diet alone. The rats were analyzed for water and feed intake, body weight, organs to body weight ratio, glucose concentration, lipid profile, lipid peroxidation test, liver cholesterol, and liver and renal function tests. The results showed that high cholesterol in diet was well managed by rat groups on apple pomace and mango peels supplement. The mango peels powder was found to be more effective as compared to apple pomace powder against hyperlipidemia. Mango peels and apple pomace powders not only improved the lipid profile but also resulted in lower liver cholesterol concentration and better lipid peroxidation status of the experimental rats as compared to control group. It can be concluded that fruit processing waste specially mango peels can be cost effective tool to manage diet induced hyperlipidemia, lipid peroxidation and fatty liver diseases.

Keywords: Antioxidants; fiber; fruit waste; lipid peroxidation; liver cholesterol

\section{ABSTRAK}

Diet teraruh hiperlipidemia adalah penyebab utama aterosklerosis, peroksidasi lipid dan penyakit hati berlemak. Serat pemakanan yang kaya dengan sisa pemprosesan buah dan keupayaan antioksidan boleh dijadikan sebagai satu cara yang ekonomi untuk menguruskan faktor risiko tersebut. Objektif utama kajian ini adalah untuk menguruskan hiperlipidemia dengan memasukkan buah epal dan kulit manga dalam diet harian. Serbuk kering yang diperoleh daripada buah epal, kulit manga dan campuran tersebut telah ditambahkan ke dalam chow biasa secara penggantian sebanyak 12\%. Makanan diberikan kepada tikus dengan diet hiperlipidemik bagi kumpulan uji kaji (N=30, 10/kumpulan), manakala kumpulan kawalan $(N=10)$ diberi makanan diet hiperlipedemik sahaja. Tikus dianalisis untuk pengambilan air dan makanan, berat badan, nisbah berat organ kepada badan, kepekatan glukosa, profil lipid, ujian peroksidasi lipid, kolesterol hati dan ujian fungsi hati dan ginjal. Hasil kajian menunjukkan bahawa kolesterol tinggi dalam makanan dapat dikendalikan dengan baik oleh kumpulan tikus dengan bahan tambahan buah epal dan kulit mangga. Serbuk kulit mangga didapati lebih berkesan jika dibandingkan dengan serbuk buah epal terhadap hiperlipidemia. Serbuk kulit mangga dan buah epal bukan sahaja meningkatkan profil lipid tetapi juga menghasilkan kepekatan kolesterol hati yang lebih rendah dan status peroksidasi lipid yang lebih baik bagi tikus eksperimen berbanding dengan kumpulan kawalan. Ini dapat disimpulkan bahawa sisa pemprosesan buah khususnya kulit mangga dapat menjadi alat yang efektif daripada segi kos untuk menguruskan hiperlipidemia yang disebabkan oleh diet, peroksidasi lipid dan penyakit hati berlemak.

Kata kunci: Antioksida; kolesterol hati; peroksidasi lipid; serat; sisa buah

\section{INTRODUCTION}

High fat diet causes hyperlipidemia resulting in atherosclerosis, oxidative damage, fatty liver diseases and other cardiovascular diseases (Chen et al. 2014; Durrington \& Soran 2014). Cardiovascular diseases are prevalent throughout the world and the morbidity and mortality due to the disease in Pakistan is also at distressing situation with about $30 \%$ of masses suffering from hyperlipidemia (Anwar et al. 2015). There are a number of other causative agents for hyperlipidemia including age, genetics, physical inactivity, overweight, and obesity (Chen et al. 2014). 
The high cost and toxic effects (muscoskeletal complaints and liver disorders) of typically used pharmaceutical agents for lipid profile and cardiovascular diseases demand the production of diet based cost effective alternatives (Hong et al. 2015). Numerous plant materials including fruits, vegetables, barks, leaves, cereals, seeds, herbs, and roots have been examined for their potential against hyperlipidemia and heart diseases. Nevertheless, relatively less information is available on the hypolipidemic potential of the huge agro-industrial wastes which are usually discarded and become a source of annoyance, specially no such study has yet been viewed using whole mango peels powder.

For the last decade, antihyperlipidemic, antioxidative, hepatoprotective, and cardioprotective roles of waste from agro-industries are gaining much attention (Nehra \& Sharma 2012). Moreover, dietary fiber, good amount of pectin and phytochemicals, sufficiently present in such wastes from fruit processing industries may be highly suitable for the management of hyperlipidemia (Nouri \& Rezapour 2011). Particularly, higher amounts of soluble dietary fiber in apple pomace $(12.36 \pm 0.21 \%)$ and mango peels powders $(21.86 \pm 0.11 \%)$ may act as cost effective modulators for lipid metabolism that also slows down the process of plaques formation (Umbreen et al. 2015).

As Pakistan is an agricultural state and is blessed with important fruits, the demand for processed fruits is increasing. The capacity of fruit juice industry in Pakistan was around 400,000 Mt with mango and apple juice most favored and liked by all age groups. With increased demand and consumption, production of waste has also increased and clearance becomes an emergent issue, so the bio-prospecting and screening for hypolipidemic components in wastes from fruit processing industries can be sound and beneficial. Therefore, this study was an attempt to investigate apple pomace and mango peels as potential sources against hyperlipidemia. It was hypothesized that higher content of dietary fiber and antioxidant capacity of these wastes as found in our earlier study (Umbreen et al. 2015) would help to combat the issues related to diet induced hyperlipidemia. Moreover, the management of higher blood lipid concentration by using the natural components may also provide a better alternate to conventional medicines such as statins which cause several side effects including muscoskeletal pain and liver toxicity. Furthermore, it may also contribute somehow towards the management of massive industrial waste that is a source of pollution and annoyance.

\section{MATERIALS AND METHODS}

\section{RAW MATERIALS AND CHEMICALS}

The waste materials from fruit processing industry i.e. apple pomace and mango peels were washed, blanched, dried, and ground according to method reported by Umbreen et al. (2015). All the chemicals and testing kits used were of analytical grade and were acquired along with basal diet materials from Sigma Aldrich (USA) and Randox laboratories (UK). The male Sprague dawley rats $(\mathrm{N}=40)$ at weanling stage (age 6 weeks) weighing 110 $\pm 5 \mathrm{~g}$ were purchased from National Institute of Health (NIH) Islamabad, Pakistan.

\section{EXPERIMENTAL ANIMAL STUDY DESIGN}

The study protocol was approved by Ethical Review Board of the University (GCERB 212). The rats were acclimatized on basal diet for seven days. The environment of the animal room was controlled at proper temperature $\left(25 \pm 2{ }^{\circ} \mathrm{C}\right)$ and relative humidity $(60$ $\pm 5 \%$ ) with $12 \mathrm{~h}$ light and dark cycles. The blood of rats was collected from jugular vein under general anesthesia using isoflurane inhalation and was analyzed for basal level of serum glucose, total cholesterol, LDL cholesterol and triglycerides. The rats were divided into four groups (10 in each group) consuming control diet $\left(\mathrm{D}_{0}\right)$, apple pomace powder (APP) enriched diet $\left(\mathrm{D}_{1}\right)$, mango peels powder (MPP) enriched diet $\left(\mathrm{D}_{2}\right)$ and mixture of apple pomace and mango peels powders (APMPP) enriched diet $\left(D_{3}\right)$. The experimental diets were prepared on replacement basis with starch and compositions of the diets are given in Table 1 (Uppal et al. 2008). The study continued for 56 days after which the rats were fasted overnight and were decapitated under anesthesia using isoflurane to get blood and organ samples.

\section{ANALYSIS OF BODY WEIGHT, FEED AND WATER INTAKE}

Net feed intake of rats was measured daily by excluding the feed spilled and remaining from given feed during whole study period and is mentioned as average $(\mathrm{g})$. Water was provided in graduated bottles and water consumed was also measured on daily basis. The changes in body weight of the rats in both studies were measured on weekly basis to check the effect of treatment on body weight.

\section{ANALYSIS OF SERUM BIOCHEMICAL PARAMETERS}

The blood was collected in clean centrifuge tubes, allowed to clot and was centrifuged at $3000 \mathrm{rpm}$ for 10 min to get clear serum (Ismail \& Abd El-Gawad 2010). The serum was extracted carefully in sterilized eppendorf tubes and was stored at $-20{ }^{\circ} \mathrm{C}$ for further analyses. The collected serum samples were tested for glucose concentration (mg/dL) (Thomas \& Labor 1992), lipid profile $(\mathrm{mg} / \mathrm{dL})$ i.e. total cholesterol (Stockbridge et al. 1989), high density lipoprotein (Assmann 1979) low density lipoprotein (McNamara et al. 1990), triglycerides (Annoni et al. 1982), very low density lipoprotein (Ismail \& Abd El-Gawad 2010) concentrations as well as HDL to total cholesterol ratio (HTR) and atherogenic index (AI) (Leontowicz et al. 2007). Antioxidant status of the rat serum was performed in terms of thiobarbituric acid reactive species (TBARS) to check lipid per-oxidation level (Ohkawa et al. 1979). 
TABLE 1. Composition of diets fed to the control and experimental rat groups $(\mathrm{g} / 100 \mathrm{~g})$

\begin{tabular}{cccccc}
\hline Ingredients g/100 g & Basal diet & $\mathrm{D}_{0}$ & $\mathrm{D}_{1}$ & $\mathrm{D}_{2}$ & $\mathrm{D}_{3}$ \\
\hline Starch & 75 & 73 & 61 & 61 & 61 \\
Apple pomace powder & 0 & 0 & 12 & 0 & 6 \\
Mango peels powder & 0 & 0 & 0 & 12 & 6 \\
Casein & 10 & 10 & 10 & 10 & 10 \\
Corn oil & 10 & 10 & 10 & 10 & 10 \\
Vitamin mixture AIN-93G & 3 & 3 & 3 & 3 & 3 \\
Mineral mixture AIN-93G & 2 & 2 & 2 & 2 & 2 \\
Cholesterol & 0 & 1.5 & 1.5 & 1.5 & 1.5 \\
Cholic acid & 0 & 0.5 & 0.5 & 0.5 & 0.5 \\
\hline Total & 100 & 100 & 100 & 100 & 100 \\
\hline
\end{tabular}

$\overline{D_{0}}$ represent control diet; $\mathrm{D}_{1}$ is replacing starch with $12 \%$ apple pomace powder; $\mathrm{D}_{2}$ is replacing starch with $12 \%$ mango peels powder; $\mathrm{D}_{3}$ is replacing starch with $12 \%$ mixture of apple pomace and mango peels powder $(6 \%$ APP and $6 \%$ MPP)

\section{ANALYSIS OF LIVER AND KIDNEYS}

At the end of the study, the rats were dissected and the liver and kidneys were collected and weighed. The values were given as organ to body weight ratios $(\mathrm{g} / 100$ g) (Ismail \& Abd El-Gawad 2010). In order to determine liver cholesterol concentration, $0.5 \mathrm{~g}$ of tissue sample from liver was homogenized with $2 \mathrm{~mL}$ of sodium chloride solution $(0.9 \%)$. The obtained sample was centrifuged for $10 \mathrm{~min}$ twice to get the clear sample, which was examined for cholesterol content $(\mu \mathrm{mol} / \mathrm{g}$ ) according to method described for serum total cholesterol (Krzeminski et al. 2003).

The concentration of liver enzymes as aspartate aminotransferase (AST), alanine aminotransferase (ALT) and alkaline phosphates (ALP) was measured using end point colorimetric method while bilirubin was measured by using Jendrassik and Grof method as explained by Etim et al. (2013). Enzyme activity was expressed in IU $\mathrm{L}^{-1}$ and amount of bilirubin was measured in $\mathrm{mg} /$ dL. Furthermore, the samples were analyzed for serum creatinine and urea concentration $(\mathrm{mg} / \mathrm{dL})$ using the method of $\mathrm{Wu}$ (2006).

\section{STATISTICAL ANALYSES}

Completely Randomized Design (CRD) was applied and the obtained data were analyzed using SPSS Inc. (Released 2008. SPSS Statistics for Windows, Version 17.0. Chicago: SPSS Inc.). For body weight, feed and water intake, two way ANOVA was used. The results have been mentioned as mean of three replicates with standard error of means (SEM). To determine the difference $(\mathrm{P} \leq 0.05, \mathrm{P} \leq 0.001)$ of means, post hoc test was performed using least significant difference (LSD).

\section{RESULTS AND DISCUSSION}

\section{BODY WEIGHT, FEED AND WATER INTAKES}

All the rats remained lively throughout the study period of 56 days. The maximum weight gain was observed for control group consuming hyperlipidemic diet only. This tendency was well managed by rats fed fruit processing waste along with the hyperlipidemic diet and showed no significant difference among APP, MPP, and APMPP consuming groups (Figure 1(A)). The least weight increase as compared to control was found for rat groups on APP and MPP supplemented diet, with more promising effect shown by MPP diet group $\left(\mathrm{D}_{2}\right)$ (Table 2). Likewise, significantly $(\mathrm{P} \leq 0.05)$ increasing trend of feed intake was observed with passage of time irrespective of group (Figure 1(B)), however, the experimental groups $\left(\mathrm{D}_{1}, \mathrm{D}_{2}\right.$, $\mathrm{D}_{3}$ ) consumed less feed as compared to control group $\left(\mathrm{D}_{0}\right)$. Whereas, an opposite tendency was found in case of water consumption (Figure 1(C)) as more water intake was observed in experimental groups than control group (Table 2). 
Significant effect of fruit processing waste on feed and water consumption and body weight may be due to the provision of high fiber by apple pomace powder $(68.46 \pm 0.11 \%)$ and mango peel powder $(64.75 \pm 0.11 \%)$ as was shown by our study on fruit processing waste (Umbreen et al. 2015). Similar results were also reported by Chen et al. (2017) in mice treated with apple pomace polysaccharides along with high fat diet. The studies have shown that higher content of fiber in diet results in increased satiety, lower energy density and decreased diet intake, so prevent obesity (Bell \& Rolls 2001). It is further reported that diets high in fiber require more mastication, stay longer in the stomach and lower postprandial secretion of insulin causing higher rate of satiety (Libuda et al. 2008). Similarly, fiber rich diets result in bacterial fermentation which suppresses feeling of hunger by increased production of short chain fatty acid (Abeywardena 2003). However, increase in water intake by the groups on high fiber diet may be due to higher fecal loses being potent cause for extracellular as well as intracellular thirst (He et al. 2010). It may also be stated that reduction in body weights of the rats in fiber fed groups is related to lower caloric density helping in weight management and satiety produced by fiber especially soluble fiber in apple pomace and mango peels powders (Cho et al. 2013).

A

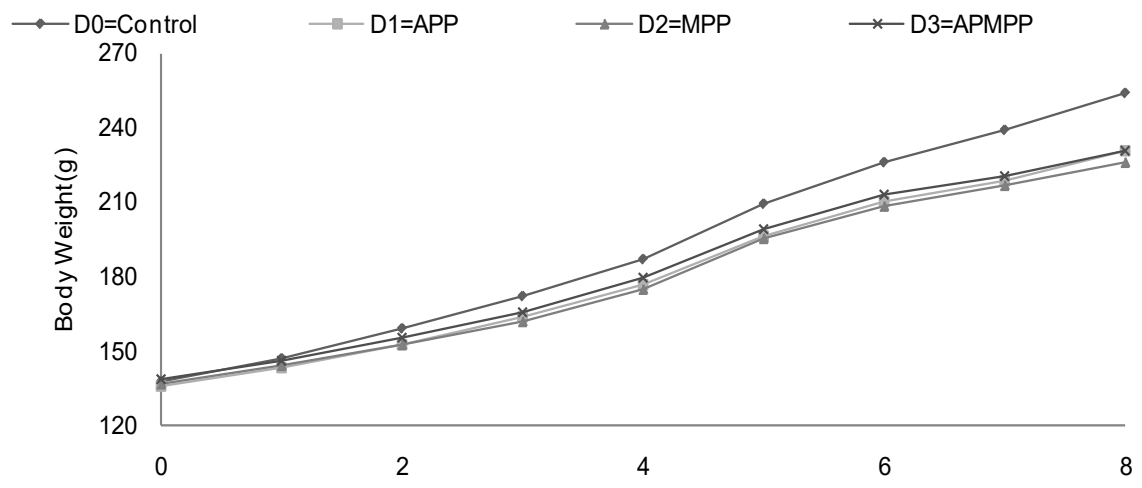

B
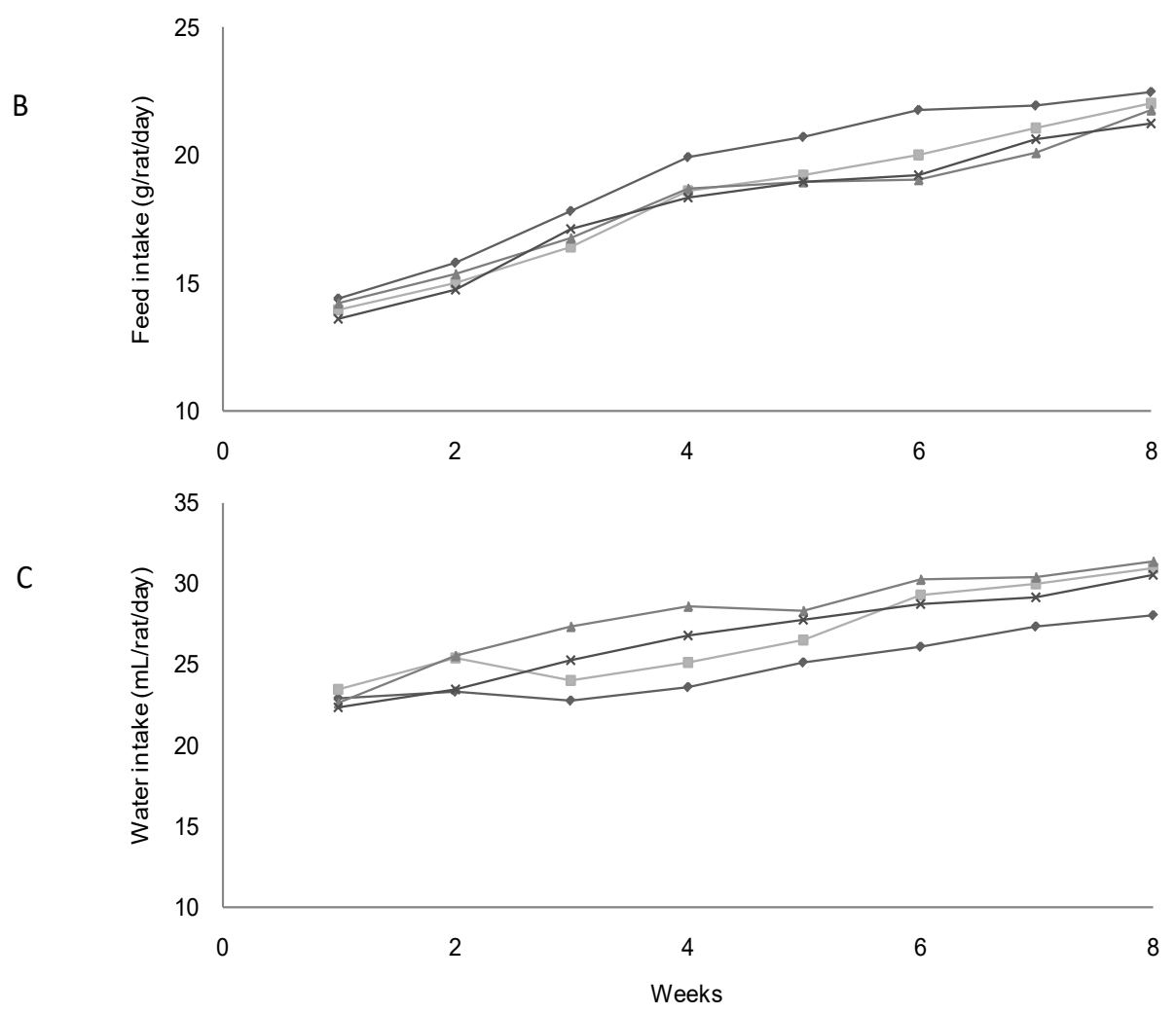

FIGURE 1. Means changes in body weight (A), feed (B) and water intakes (C) of different rat groups on weekly basis during the study period of 8 weeks for control $\left(\mathrm{D}_{0}\right)$, Apple pomace powder supplemented $\left(D_{1}\right)$, Mango peels powder supplemented $\left(D_{2}\right)$ and mixture of apple pomace and mango peels power supplemented $\left(\mathrm{D}_{3}\right)$ diets. Data were analyzed by two way ANOVA followed by LSD at $\mathrm{P} \leq 0.05 \mathrm{~N}=40,10$ /group 
TABLE 2. Effect of supplementation of apple pomace powder, mango peels powder and combination on physical parameters of different rat groups

\begin{tabular}{|c|c|c|c|c|}
\hline & Body weight gain (g) & Feed intake (g) & Water intake $(\mathrm{mL})$ & $\begin{array}{c}\text { Weight reduction } \\
\text { compared to control }(\%)\end{array}$ \\
\hline $\mathrm{D}_{0}$ & $192.61 \pm 1.17^{\mathrm{a}}$ & $19.51 \pm 0.18^{\mathrm{a}}$ & $24.17 \pm 0.22^{\mathrm{c}}$ & - \\
\hline $\mathrm{D}_{1}$ & $181 \pm 1.26^{\mathrm{c}}$ & $18.32 \pm 0.21^{\mathrm{b}}$ & $26.86 \pm 0.25^{\mathrm{b}}$ & 8.87 \\
\hline $\mathrm{D}_{2}$ & $179.67 \pm 1.11^{\mathrm{c}}$ & $18.12 \pm 0.16^{\mathrm{b}}$ & $28.21 \pm 0.18^{\mathrm{a}}$ & 10.84 \\
\hline $\mathrm{D}_{3}$ & $183.18 \pm 1.02^{\mathrm{b}}$ & $18 \pm 0.16^{\mathrm{b}}$ & $26.79 \pm 0.17^{\mathrm{b}}$ & 10.11 \\
\hline $\begin{array}{l}\text { The feed } \\
\text { using on } \\
{ }^{b c} \text { ), in a } \\
\text { is replaci } \\
6 \% \text { MPP) }\end{array}$ & $\begin{array}{l}\text { rater intake was measured on } \\
\text { ANOVA followed by LSD. Al } \\
\text { n represent the significant dif } \\
\text { rch with } 12 \% \text { mango peels p }\end{array}$ & $\begin{array}{l}\text { pasis and body weight } \\
\text { s are means } \pm \text { SE of res } \\
\text { es at } P \leq 0.05 . D_{0} \text { repres } \\
D_{3} \text { is replacing starch }\end{array}$ & $\begin{array}{l}\text { ly basis for whole study } \mathrm{p} \\
\text { ined from different rat gr } \\
\text { rol diet; } \mathrm{D}_{1} \text { is replacing st } \\
\% \text { mixture of apple poma }\end{array}$ & $\begin{array}{l}\text { (56th day). The data were analyze } \\
(\mathrm{n}=40,10 \text { /group). Different letters } \\
\text { with } 12 \% \text { apple pomace powder; } D \\
\text { d mango peels powder ( } 6 \% \text { APP an }\end{array}$ \\
\hline
\end{tabular}

\section{GLUCOSE, LIPID PROFILE AND LIPID PEROXIDATION STATUS}

The highest glucose, serum total cholesterol, VLDL-chol, LDL-chol and triglyceride levels were found for the rats in control group consuming high fat diet compared to baseline values. However, it was well managed by rats consuming apple pomace and mango peels powder along with hyperlipidemic diet and the best results were shown by MPP diet group. Moreover, HDL concentration and HDL to total cholesterol ratio (HTR) (Table 3) increased significantly $(\mathrm{P} \leq 0.001)$ (APP $44.13 \%$, MPP $58.85 \%$, APMPP $49.6 \%$ ) in the rats on diet supplemented with fruit processing waste compared to control group $\left(\mathrm{D}_{0}\right)$ on high fat diet alone. The atherogenic index (AI) increased significantly in control group consuming hyperlipidemic diet but was well maintained by groups on diet enriched with fruit processing waste + hyperlipidemic diet and the least value was observed in group on MPP supplementation (Table 3). The mean concentrations for serum thiobarbituric acid reactive substances (TBARS) showed significant difference $(\mathrm{P} \leq 0.001)$ among the various rat groups. The least value of TBARS (5.91 \pm 0.08 $\mathrm{nmol} / \mathrm{mL})$ was observed in groups fed MPP $\left(\mathrm{D}_{2}\right)$ followed by $\mathrm{D}_{1}$ and $\mathrm{D}_{3}$ showing resistance against increase in oxidative stress (Figure 2).

The fall in glucose level in experimental groups $\left(\mathrm{D}_{1}, \mathrm{D}_{2}, \mathrm{D}_{3}\right)$ of the present study might be attributed to presence of soluble fiber in APP $(12.36 \pm 0.21 \%)$ and MPP $(21.86 \pm 0.11 \%)$, which resulted in a reduction in gastric emptying rate and slower absorption of macronutrient (Lattimer \& Haub 2010; Umbreen et al. 2015). Similarly, Maghrani et al. (2005) proposed that increased flavonoids from the plant sources inhibit the re-absorption of glucose via symporters present in proximal distal tubule of kidneys. The most probable mechanism for reduction in serum cholesterol levels by dietary fiber is physically chelating bile acids out of body (Abeywardena 2003). Moreover, the bile salts re-entry into blood is restricted by increased viscosity of distal ileum contents, thus fecal excretion is increased altering cholesterol metabolism (Amer et al. 2012). The reduced VLDL concentration might be caused by depletion in liver pool due to consumption of fiber sources from agro-industrial wastes especially MPP. The decreased liver VLDL alters lipoprotein metabolism with reduced cholesteryl esters, the composition of VLDL is adapted accordingly causing its less conversion to IDL and LDL. Another reason for reduced VLDL concentration by fiber rich diets is lowered amount of cholesteryl ester transfer protein (CETP) contributing to reduced cholesterol in blood (Conn 2008).

Serum HDL to total cholesterol ratio (HTR) is a key interpreter for cardiac manifestations and its decreased value shows reduced risk of such diseases. Consequently, the adaptation of APP and MPP fed groups against high cholesterol diet in improving HTR depicted its cardioprotective role. Similarly, atherogenic index is a sign of lipid deposition or plaque formation or presence of foam cells in coronary arteries, aorta, liver, and kidneys, while higher level is a probable mark for oxidative stress resulting in coronary artery disease (CAD) (Basu et al. 2007). Therefore, the reduced level of AI in the rat groups on fiber rich diets, especially MPP may designate it as a low risk therapy against management of CAD. In 
accordance with the present described that apple pomace and apple juice concentrate ameliorate the harmful cardiovascular effects of high fat diet. Furthermore, similar results were also reported by feeding various other fiber sources by some other studies (Afify et al. 2013; Ismail \& Abd El-Gawad 2010; Nouri \& Rezapour 2011; Shah et al. 2010) and the improvements were accredited to high dietary fiber and phytochemicals modulating the formation and absorption of cholesterol.

Moreover, decline in TBARS value in present study is indicative that the apple pomace and mango peel antioxidants $\left(\mathrm{IC}_{50}\right.$ value $\mathrm{APP}=17.65 \pm 0.17$ and $\mathrm{MPP}=2.94 \pm 0.18 \mu \mathrm{g} / \mathrm{mL}$, respectively) have good bioavailability in the body (Abd El-Ghany et al. 2011). Being by product of lipid peroxidation, TBARS acts as biomarker for oxidation taking place in body; however, its decreased concentration in blood shows an improved antioxidant level. The results are in line with the findings of earlier studies, which described that addition of apple pomace and mango peels powder may improve the oxidative stress due to high fat diets (Chen et al. 2017; Jahurul et al. 2015).

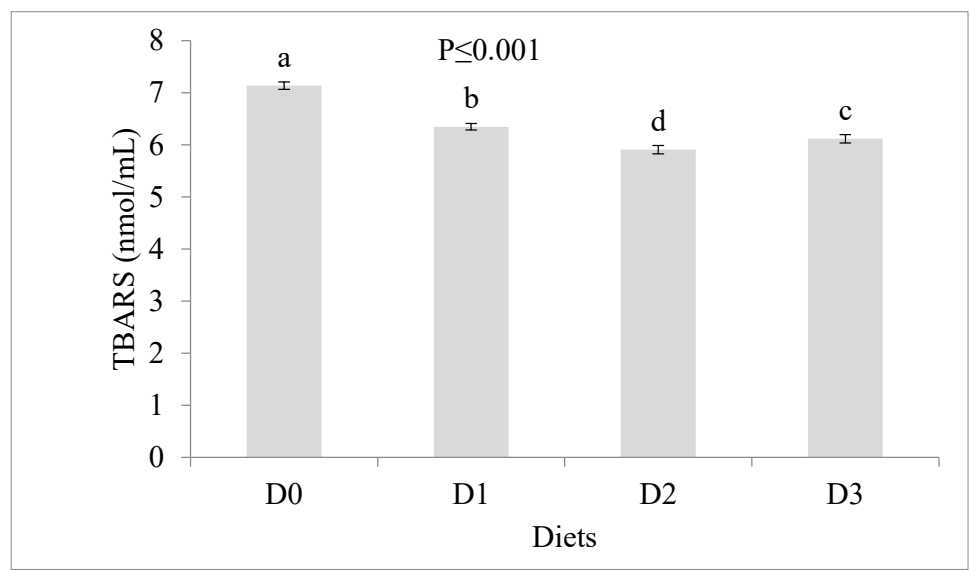

FIGURE 2. Serum values of thiobarbituric acid reactive substance concentration of rat groups for control $\left(\mathrm{D}_{0}\right)$, Apple pomace powder supplemented $\left(\mathrm{D}_{1}\right)$, Mango peels powder supplemented $\left(D_{2}\right)$ and mixture of apple pomace and mango peels power supplemented $\left(D_{3}\right)$ diets. Data were analyzed by one way ANOVA followed by LSD. Data is presented as mean \pm SE. Values having different labels show significant difference at $\mathrm{P} \leq 0.001 \mathrm{~N}=40,10$ /group

TABLE 3. Effect of supplementation of apple pomace powder, mango peels powder and combination on serum glucose and lipid profile of different rat groups

\begin{tabular}{|c|c|c|c|c|c|c|c|c|}
\hline & Glucose & $\begin{array}{l}\text { Total } \\
\text { Chol. }\end{array}$ & $\begin{array}{l}\text { LDL- } \\
\text { Chol. }\end{array}$ & $\begin{array}{l}\text { HDL- } \\
\text { Chol. }\end{array}$ & $\begin{array}{l}\text { VLDL- } \\
\text { Chol. }\end{array}$ & $\begin{array}{c}\text { Tri- } \\
\text { Glycerides }\end{array}$ & $\begin{array}{l}\text { HDL/Total } \\
\text { Chol. Ratio }\end{array}$ & $\begin{array}{c}\text { Atherogenic } \\
\text { Index }\end{array}$ \\
\hline & \multicolumn{8}{|c|}{$(\mathrm{mg} / \mathrm{dL})$} \\
\hline \multirow{2}{*}{ Baseline } & 68.77 & 79.43 & 27.19 & 39.01 & 14.02 & 70.12 & 0.49 & 1.03 \\
\hline & $\pm 2.01^{\mathrm{c}}$ & $\pm 1.68^{\mathrm{e}}$ & $\pm 1.24^{\mathrm{c}}$ & \pm 1.85 & $\pm 1.11^{\mathrm{d}}$ & $\pm 2.02^{\mathrm{d}}$ & $\pm 0.08^{\mathrm{a}}$ & $\pm 0.12^{\mathrm{e}}$ \\
\hline \multirow{2}{*}{$\mathrm{D}_{0}$} & 94.72 & 146.08 & 62.99 & 28.9 & 20.39 & 101.95 & 0.19 & 4.05 \\
\hline & $\pm 1.34^{\mathrm{a}}$ & $\pm 1.49^{\mathrm{a}}$ & $\pm 1.42^{\mathrm{a}}$ & $\pm 1.07^{\mathrm{c}}$ & $\pm 0.25^{\mathrm{a}}$ & $\pm 1.68^{\mathrm{a}}$ & $\pm 0.01^{\mathrm{d}}$ & $\pm 0.04^{\mathrm{a}}$ \\
\hline \multirow{2}{*}{$\mathrm{D}_{1}$} & 81.19 & 116.3 & 44.71 & 32.56 & 17.33 & 86.67 & 0.28 & 2.57 \\
\hline & $\pm 1.17^{\mathrm{b}}$ & $\pm 1.74^{\mathrm{b}}$ & $\pm 1.02^{\mathrm{b}}$ & $\pm 0.85^{\mathrm{b}}$ & $\pm 0.43^{\mathrm{b}}$ & $\pm 1.21^{\mathrm{b}}$ & $\pm 0.01^{\mathrm{c}}$ & $\pm 0.02^{\mathrm{b}}$ \\
\hline \multirow{2}{*}{$\mathrm{D}_{2}$} & 79.41 & 107.09 & 41.89 & 33.42 & 16.84 & 84.23 & 0.31 & 2.2 \\
\hline & $\pm 1.19^{\mathrm{b}}$ & $\pm 1.02^{\mathrm{d}}$ & $\pm 1.41^{\mathrm{bc}}$ & $\pm 1.03^{\mathrm{b}}$ & $\pm 0.52^{\mathrm{c}}$ & $\pm 0.89^{\mathrm{c}}$ & $\pm 0.02^{\mathrm{a}}$ & $\pm 0.03^{\mathrm{d}}$ \\
\hline \multirow{2}{*}{$\mathrm{D}_{3}$} & 79.98 & 110.42 & 42.78 & 32.93 & 17.01 & 85.05 & 0.29 & 2.36 \\
\hline & $\pm 1.27^{\mathrm{b}}$ & $\pm 1.59^{\mathrm{c}}$ & $\pm 1.32^{\mathrm{b}}$ & $\pm 0.93^{\mathrm{a}}$ & $\pm 0.27^{\mathrm{bc}}$ & $\pm 2.02^{\mathrm{bc}}$ & $\pm 0.01^{\mathrm{b}}$ & $\pm 0.02^{\mathrm{c}}$ \\
\hline
\end{tabular}

The values were measured at baseline ( 0 day) and end of the study period (56th day). The data were analyzed using one-way ANOVA followed by LSD. All values are means \pm SE of results obtained from different rat groups ( $\mathrm{n}=40,10$ /group). Different letters $\left({ }^{\mathrm{a} b} \mathrm{c}\right)$, in a column represent the significant differences at $\mathrm{P} \leq 0.001$. $\mathrm{D}_{0}$ represent control diet; $\mathrm{D}_{1}$ is replacing starch with $12 \%$ apple pomace powder; $\mathrm{D}_{2}$ is replacing starch with $12 \%$ mango peels powder; $\mathrm{D}_{3}$ is replacing starch with $12 \%$ mixture of apple pomace and mango peels powder ( $6 \%$ APP and $6 \%$ MPP) 


\section{LIVER AND KIDNEY PROFILE STUDY}

The means for organ weight per $100 \mathrm{~g}$ of body weight (Table 3) did not show any significant difference $(\mathrm{P} \leq 0.05)$ in weight of kidneys while liver of control group had a higher weight compared with experimental groups. Furthermore, liver cholesterol concentration showed a decreasing trend in experimental $\left(D_{1}=9.44\right.$, $\left.\mathrm{D}_{2}=7.99, \mathrm{D}_{3}=8.73 \mu \mathrm{mol} / \mathrm{g}\right)$ as compared to control group $(15.65 \mu \mathrm{mol} / \mathrm{g})$ (Figure 3$)$. The results of serum alanine aminotransferase (ALT) aspartate amino transferase (AST), alkaline phosphatase (ALP), bilirubin, urea, and creatinine concentrations among various rat groups varied significantly $(\mathrm{P}<0.05)$, with the maximum concentrations in the rat group on high fat basal diet $\left(\mathrm{D}_{0}\right)$. Contrarily, the blood concentrations in rat groups on APP $\left(D_{1}\right)$, MPP $\left(D_{2}\right)$, and APMPP $\left(D_{3}\right)$ supplemented diets were comparable to the baseline values and showed resistance against any unwanted changes in liver and renal function tests (Table 4).

The increase in concentration of serum ALT, AST, and ALP is attributed to degenerative alterations in liver. Therefore, the increased concentration in control group is related to deterioration occurring in liver due to consumption of diet rich in fat and similar effects with liver were also observed by Chen et al. (2017) in groups fed high fat diet. Furthermore, the resistance against any negative alteration in liver function by the groups fed apple pomace and mango peels powders along with high fat diet has demonstrated its hepato-protective function and might be attractive remedy against liver diseases (Chen et al. 2017; Sallie et al. 1991). The antioxidant potential of apple pomace and mango peels acts as hepato-protectors against oxidative damage contributed by reactive oxygen species (ROS) (Chen et al. 2017; Mahmoed \& Rezq 2013). Furthermore, APP, MPP, and APMPP mediated decrease in bilirubin content of serum represents its ability to recover biliary dysfunction induced by fat rich diet.

The reduction in serum urea concentration in rat groups on APP, MPP, and APMPP supplemented diet compared to control group is attributable to higher colonic fermentation by intake of fiber. In the intestine, bacteria trap nitrogen as cellular protein, whereas more diffusible ammonia is changed to ammonium ion (less diffusible). Such alterations cause more nitrogen excretion through feces and is used to minimize blood urea in renal failure patients (Jenkins et al. 1997). Likewise, creatinine is excreted through kidneys and in case of poor filtration, its blood level is increased (Allen 2012). Elevated serum creatinine in control group was a side effect of high fat diet; which was well managed by rat groups on APP, MPP, and APMPP supplementation along with hyperlipidemic diet. In accordance with the present results, Afify et al. (2013) also reported the improved liver and renal function tests with carrot pomace supplementation in rats fed high fat diets.

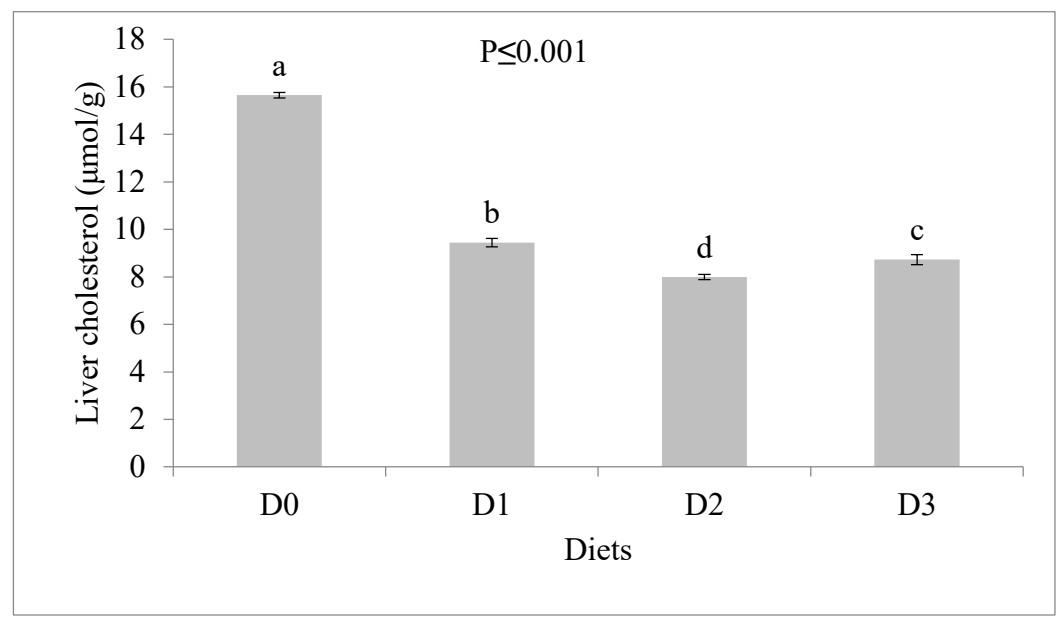

FIGURE 3. Values of liver cholesterol concentration of rat groups for control $\left(\mathrm{D}_{0}\right)$, Apple pomace powder supplemented $\left(D_{1}\right)$, Mango peels powder supplemented $\left(D_{2}\right)$ and mixture of apple pomace and mango peels power supplemented $\left(\mathrm{D}_{3}\right)$ diets. Data was analyzed by one way ANOVA followed by LSD. Data is presented as mean \pm SE. Values having different labels show significant difference at $\mathrm{P} \leq 0.001 \mathrm{~N}=40,10$ /group 
TABLE 4. Effect of supplementation of apple pomace powder, mango peels powder and combination on liver and kidneys weight, liver enzymes and renal function of different rat groups

\begin{tabular}{|c|c|c|c|c|c|c|c|c|c|}
\hline Diets & $\begin{array}{c}\text { Liver } \\
\text { (g/100 g) }\end{array}$ & $\begin{array}{l}\text { Left Kidney } \\
\qquad(\mathrm{g} / 100 \mathrm{~g})\end{array}$ & $\begin{array}{l}\text { Right Kidney } \\
\text { (g/100 g) }\end{array}$ & $\begin{array}{l}\text { ALT } \\
(\mathrm{IU} / \mathrm{L})\end{array}$ & $\begin{array}{l}\text { AST } \\
(\mathrm{IU} / \mathrm{L})\end{array}$ & $\begin{array}{l}\text { ALP } \\
(\mathrm{IU} / \mathrm{L})\end{array}$ & $\begin{array}{l}\text { Bilirubin } \\
(\mathrm{mg} / \mathrm{dL})\end{array}$ & $\begin{array}{c}\text { Urea } \\
(\mathrm{mg} / \mathrm{dL})\end{array}$ & $\begin{array}{r}\text { Creatinine } \\
(\mathrm{mg} / \mathrm{dL})\end{array}$ \\
\hline \multirow{2}{*}{ Baseline } & \multirow{2}{*}{-} & \multirow{2}{*}{ - } & \multirow{2}{*}{-} & 33.4 & 71.62 & 131.92 & 0.57 & 19.33 & 0.68 \\
\hline & & & & $\pm 1.18^{\mathrm{c}}$ & $\pm 2.02^{\mathrm{c}}$ & $\pm 2.16^{\mathrm{d}}$ & $\pm 0.03^{\mathrm{c}}$ & $\pm 0.96^{\mathrm{c}}$ & $\pm 0.02^{\mathrm{c}}$ \\
\hline \multirow{2}{*}{$\mathrm{D}_{0}$} & 4.87 & 0.53 & 0.53 & 50.58 & 134.85 & 225.8 & 0.89 & 29.13 & 0.908 \\
\hline & $\pm 0.04^{\mathrm{a}}$ & \pm 0.02 & \pm 0.01 & $\pm 1.07^{\mathrm{a}}$ & $\pm 0.46^{\mathrm{a}}$ & $\pm 0.97^{\mathrm{a}}$ & $\pm 0.03^{\mathrm{a}}$ & $\pm 0.45^{\mathrm{a}}$ & $\pm 0.008^{\mathrm{a}}$ \\
\hline \multirow{2}{*}{$\mathrm{D}_{1}$} & 4.79 & 0.54 & 0.53 & 48.87 & 116.1 & 199.86 & 0.71 & 27.21 & 0.78 \\
\hline & $\pm 0.09^{\mathrm{b}}$ & \pm 0.02 & \pm 0.02 & $\pm 0.43^{\mathrm{ab}}$ & $\pm 0.3^{\mathrm{b}}$ & $\pm 1.69^{\mathrm{bc}}$ & $\pm 0.03^{\mathrm{b}}$ & $\pm 0.5^{\mathrm{b}}$ & $\pm 0.004^{\mathrm{b}}$ \\
\hline \multirow{2}{*}{$\mathrm{D}_{2}$} & 4.76 & 0.54 & 0.54 & 48.3 & 114.5 & 198.33 & 0.71 & 26.51 & 0.76 \\
\hline & $\pm 0.07^{\mathrm{b}}$ & \pm 0.03 & \pm 0.01 & $\pm 0.46^{\mathrm{b}}$ & $\pm 0.54^{\mathrm{b}}$ & $\pm 0.95^{\mathrm{c}}$ & $\pm 0.01^{\mathrm{b}}$ & $\pm 0.5^{\mathrm{b}}$ & $\pm 0.01^{\mathrm{b}}$ \\
\hline \multirow{2}{*}{$\mathrm{D}_{3}$} & 4.77 & 0.54 & 0.54 & 48.16 & 115.42 & 203.36 & 0.72 & 27 & 0.78 \\
\hline & $\pm 0.04^{\mathrm{b}}$ & \pm 0.01 & \pm 0.03 & $\pm 0.26^{\mathrm{b}}$ & $\pm 0.38^{\mathrm{bc}}$ & $\pm 1.18^{\mathrm{b}}$ & $\pm 0.02^{\mathrm{b}}$ & $\pm 0.5^{\mathrm{b}}$ & $\pm 0.007^{\mathrm{b}}$ \\
\hline
\end{tabular}

The values were measured at baseline ( 0 day) and end of the study period (56th day). The data were analyzed using one-way ANOVA followed by LSD. All values are means \pm SE of results obtained from different rat groups ( $n=40,10$ /group). Different letters $\left({ }^{a b c}\right.$ ), in a column represent the significant differences at $P \leq 0.05$. $D_{0}$ represent control diet; $\mathrm{D}_{1}$ is replacing starch with $12 \%$ apple pomace powder; $\mathrm{D}_{2}$ is replacing starch with $12 \%$ mango peels powder; $\mathrm{D} 3$ is replacing starch with $12 \%$ mixture of apple pomace and mango peels powder (6\% APP and $6 \%$ MPP)

\section{CONCLUSION}

On the bases of the results obtained from the present study, it can be proposed that fruit waste as mango peels and apple pomace after some processing can be a good remedy against diet induced hyperlipidemia. Particularly mango peels showed promising effects against increased lipid concentration, lipid peroxidation and fatty liver disease induced by hyperlipidemic diet. Therefore, further research using apple pomace and mango peels for human subjects suffering from hyperlipidemia is recommended.

\section{ACKNOWLEDGEMENTS}

This research work was part of $\mathrm{PhD}$ thesis submitted to Higher Education Commission, Pakistan. The authors are thankful to Higher Education Commission of Pakistan for providing research grant under Indigenous Scholarship Batch VII, to Huma Umbreen (Av7-141), which paved the way towards the completion of the $\mathrm{PhD}$ research work.

\section{REFERENCES}

Abd El-Ghany, M.A., Ramdan, M.A. \& Hassanain, M.S.S. 2011. Antioxidant activity of some agro-industrial peels on liver and kidney of rats exposed to oxidative stress. World Journal of Dairy and Food Science 6: 105-114.

Abeywardena, M.Y. 2003. Dietary fats, carbohydrates and vascular disease: Sri Lankan perspectives. Atherosclerosis 171(2): 157-161.

Afify, A.M.M.R., Romeilah, R.R.M., Osfor, M.M.H. \& Elbahnasawy, A.S.M. 2013. Evaluation of carrot pomace (Daucus carota L.) as hypocholesterolemic and hypolipidemic agent on albino rats. Notulae Scientia Biologicae 5(1): 7-14.

Allen, P.J. 2012. Creatine metabolism and psychiatric disorders: Does creatine supplementation have therapeutic values? Neuroscience Biobehaviour Review 36(5): 14421462.

Amer, N., Al-Hilfy, J.H.Y. \& AL-Taie, M.A.K. 2012. Effect of apple-lite contained of apple fibers and apple gel pectin on body weight, lipid profiles, kidney function and histological structure of kidney in male albino rats. Diyala Journal of Pure Sciences 8(2): 178-187. 
Annoni, G., Botasso, B.M., Ciac, D., Donato, M.F. \& Tripodi A. 1982. Liquid triglycerides (GPO-PAP). Journal of Laboratory and Clinical Medicine 9: 115.

Anwar, H., Rahman, Z., Sohail, M.U., Iftikhar, A., Hussain, G., IrfanUllah, M., Ali, M.A. \& Shaukat, A. 2015. Evaluation of health biomarkers in hyperlipidemic albino rabbits after treatment with Withania somnifera and Lactuca scariola. Pakistan Journal of Life and Social Science 13(1): 31-36.

Assmann, G. 1979. HDL-cholesterol precipitant. Randox Labs Manual-HDL Cholesterol. Ireland.

Basu, M., Prasad, R., Jayamurthy, P., Pal, K., Arumughan, C. \& Sawhney, R.C. 2007. Anti-atherogenic effects of seabuckthorn (Hippophaeal rhamnoides) seed oil. Phytomedicine 14: 770-777.

Bell, E.A. \& Rolls, B.J. 2001. Energy density of foods affects energy intake across multiple levels of fat content in lean and obese women. The American Journal of Clinical Nutrition 73(6): 1010-1018.

Chen, G., Wang, H., Zhang, X. \& Yang, S. 2014. Nutraceuticals and functional foods in the management of hyperlipidemia. Critical Reviews in Food Science and Nutrition 54(9): 1180-1201.

Chen, L., Liu, L., Li, C., Hu, L.C., Su, F., Liu, R., Zeng, M., Zhao, D., Liu, J., Guo, Y. \& Long, J. 2017. A mix of apple pomace polysaccharide improves mitochondrial function and reduces oxidative stress in the liver of high-fat dietinduced obese mice. Molecular Nutrition in Food Research 61(3): 1600433

Cho, K.D., Han, C. \& Lee, B. 2013. Loss of body weight and fat and improved lipid profiles in obese rats fed apple pomace or apple juice concentrate. Journal of Medicinal Foods 6(9): 823-830.

Conn, P.M. 2008. Source Book of Models for Biomedical Research. New Jersey: Humana Press.

Durrington, P. \& Soran, H. 2014. Metabolism of Human Diseases. Switzerland: Springer

Etim, E.I., Essien, E.E., Eseyin, O.A. \& Udoh, I.E. 2013. Effect of some artemisinin and combination therapy regimens with and without concomitant administration of phospholipids on the levels of plasma aminotransferases and bilirubin in Nigerian male subjects. African Journal of Pharmacology and Therapeutics 2(1): 17-25.

He, M., van Dam, R.M., Rimm, E., Hu, F.B. \& Qi, L. 2010. Whole grain, cereal fiber, bran and germ intake and the risk of all cause and cardiovascular disease-specific mortality among women with type 2 diabetes mellitus. Circulation 121(20): 2162-2168.

Hong, M.Y., Nicole, H., Katy, K., Shirin, H., Arturo, F. \& Mark, K. 2015. Watermelon consumption improves inflammation and antioxidant capacity in rats fed an atherogenic diet. Nutrition Research 35(3): 251-258.

Ismail, R.S.A. \& Abd, El-Gawad. 2010. Potential effect of Egyptian Anna apple pomace (Malus domestica, Rosaceae) supplementation on kidney function, liver function and lipid profile of diabetic rats. World Journal of Dairy and Food Science 5: 58-66.

Jahurul, M.H.A., Zaidul, I.S.M., Ghafoor, K., Al-Juhaimi, F.Y., Nyam, K., Norulaini, N.A.N., Sahena, F. \& Omar, A.K.M. 2015. Mango (Mangifera indica L.) by-products and their valuable components: A review. Food Chemistry 183: 173180.
Jenkins, D.J., Popovich, D.G., Kendall, C.W., Vidgen, E., Tariq, N., Ransom, T.P., Wolever, T.M., Vuksan, V., Mehling, C.C., Boctor, D.L., Bolognesi, C., Huang, J. \& Patten, R. 1997. Effect of a diet high in vegetables, fruit, and nuts on serum lipids. Metabolism 46(5): 530-537.

Krzeminski, R., Gorinstein, S., Leontowicz, H., Leontowicz, M., Gralak, M., Czerwinski, J., Lojek, A., Číž, M., MartinBelloso, M., Gligelmo-Miguel, N. \& Trakhtenberg, S. 2003. Effect of different olive oils on bile excretion in rats fed cholesterol-containing and cholesterol-free diets. Journal of Agriculture and Food Chemistry 51(19): 5774-5779.

Lattimer, J.M. \& Haub, M.D. 2010. Effects of dietary fiber and its components on metabolic health. Nutrients 2(12): 1266-1289.

Leontowicz, H., Leontowicz, M., Gorinstein, S., Martin-Belloso, O. \& Trakhtenberg, S. 2007. Apple peels and pulp as a source of bioactive compounds and their influence on digestibility and lipid profile in normal and atherogenic rats. Medycyna Wet 63(11): 1434-1436.

Libuda, L., Alexy, U., Sichert-Hellert, W., Stehle, P., KaraolisDanckert, N., Buyken, A.E. \& Kersting, M. 2008. Pattern of beverage consumption and long-term association with body weight status in German adolescents. British Journal of Nutrition 99(6): 1370-1379.

Maghrani, M., Michel, J.B. \& Eddouks, M. 2005. Hypoglycaemic activity of Retama raetm in rats. Phytotherapy Research 19(2): 125-128

Mahmoed, M.Y. \& Rezq, A.A. 2013. Hepatoprotective effect of avocado fruits against carbon tetrachloride-induced liver damage in male rats. World Applied Science Journal 21(10): 1445-1452.

McNamara, J.R., Cohn, J.S., Wilson, P.W. \& Schaefer, E.J. 1990 Calculated values for low density lipoprotein cholesterol in the assessment of lipid abnormalities and coronary disease risk. Clinical Chemistry 36(1): 36-42.

Nehra, M. \& Sharma, S.A. 2012. Determination of total carotenoids, total phenols, ascorbic acid content and radical scavenging activity of pomegranate, papaya and orange peels. Food Science 1(5): 55-56.

Nouri, M.K. \& Rezapour, A.K. 2011. Effect of apple (Malus domestica) supplementation on serum lipids and lipoproteins level in cholesterol-fed male rat. Middle-East Journal of Scientific Research 9(6): 744-748.

Ohkawa, H., Ohishi, N. \& Yagi, K. 1979. Assay for lipid peroxides in animal tissues by thiobarbituric acid reaction. Analytical Biochemistry 95(2): 351-358.

Sallie, R., Tredger, J.M. \& William, R. 1991. Drugs and the liver Part 1: Testing liver function. Biopharmceutics and Drug Disposition 12(4): 251-259.

Shah, K.A., Patel, M.B., Shah, S.S., Chauhan, K.N., Parmar, P.K. \& Patel, N.M. 2010. Antihyperlipidemic activity of Mangifera indica L. leaf extract on rats fed with high cholesterol diet. Der Pharmacia Sinica 1(2): 156-161.

Stockbridge, H., Hardy, R.I. \& Glueck, C.J. 1989. Photometric determination of cholesterol (CHOD-PAP method). Journal of Laboratory and Clinical Medicine 114: 142151.

Thomas, L. \& Labor, U. 1992. Enzymateischer kinetischer colorimetrischer test (GOD-PAP), Biocon Diagnostik, Hecke 8, 34516 Vohl/Manenhagen, Germany. Diagnose 4: 169 . 
Umbreen, H., Arshad, M.U., Saeed, F., Bhatty, N. \& Hussain, A.I. 2015. Probing the functional potential of agro-industrial waste for dietary interventions. Journal of Food Processing and Preservation 39(6): 1665-1671.

Uppal, H., Zhai, Y., Gangopadhyay, A., Khadem, S., Ren, S., Moser, J.A. \& Xie, W. 2008. Activation of liver X receptor sensitizes mice to gallbladder cholesterol crystallization. Hepatology 47(4): 1331-1342.

Wu, A.H.B. 2006. Tietz Clinical Guide to Laboratory Tests. 4th edition. Philadelphia: WB Saunders.

Huma Umbreen* \& Muhammad Umair Arshad Institute of Home and Food Sciences

GC University

Faisalabad

Pakistan
Razia Noreen

Department of Biochemistry

GC University

Faisalabad

Pakistan

Kiran Aftab

Department of Chemistry

GC University

Faisalabad

Pakistan

*Corresponding author; email: huma_umbreen@yahoo.com

Received: 18 October 2018

Accepted: 17 February 2020 